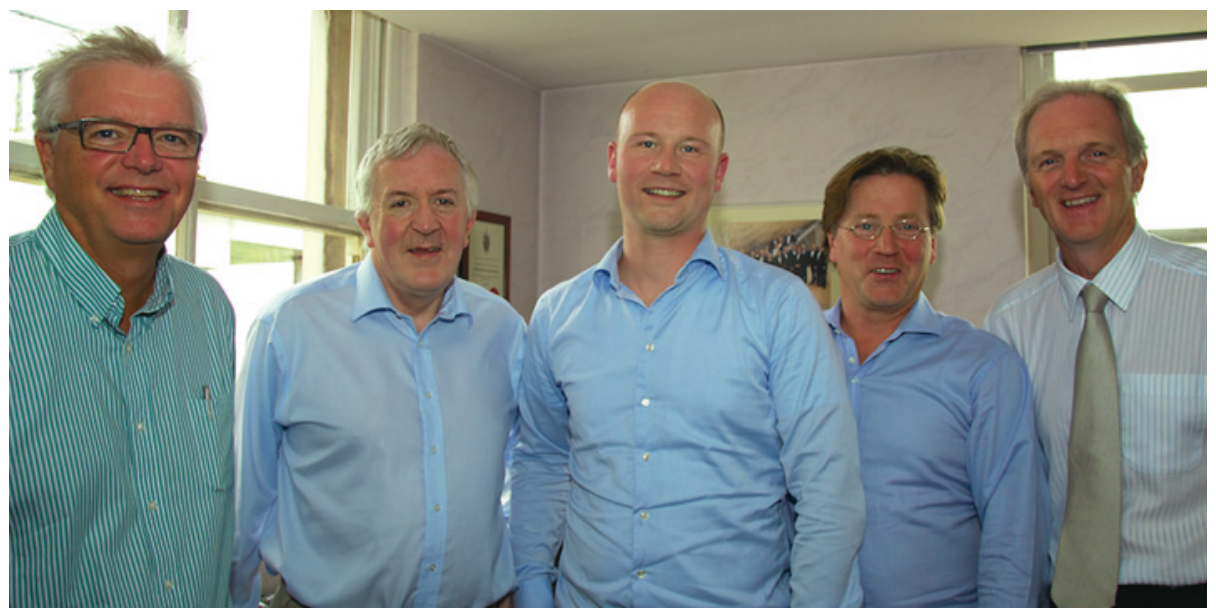

Fra venstre mot høyre: Anders Bergenfelz (Sverige), Derek Alderson (Storbritannia), Kjetil Søreide (Norge), Cornelius Dejong (Nederland) og Jonothan Earnshaw (Storbritannia), alle redaktører i British Journal of Surgery. Foto Alison Cherrie, British Journal of Surgery

\title{
Hvordan kan kirurgisk forskning styrkes?
}

\author{
Økt samarbeid over landegrensene kan gi bedre kirurgi, særlig i fattige \\ land, og kan gjøre det mulig å etablere større studier.
}

Forskningen innen kirurgiske fag har ikke hatt samme positive utvikling som forskning innen fag som infeksjonsmedisin og farmakologi. På verdensbasis utføres det hvert år nærmere 245 millioner kirurgiske inngrep, men færre enn $1 \%$ av de kirurgiske pasientene inkluderes i kliniske studier, og enda færre inngår i internasjonale forskningsprosjekter.

En internasjonal arbeidsgruppe med kirurger fra flere land har sett på strategier for internasjonalt samarbeid som kan styrke kirurgisk forskning (1). Resultatet av dette arbeidet er nylig publisert i The Lancet, og artikkelens førsteforfatter er norsk. I rapporten presenteres flere mulige strategier for internasjonalt forskningssamarbeid og det gis eksempler på vellykkede samarbeid med ulike studiedesign. Formålet med rapporten er å skape økt bevissthet om hvilke muligheter som finnes for internasjonal forskning innen kirurgi og å motivere kirurger til å drive mer klinisk forskning.

- Økt samarbeid kan bidra til å bedre det kirurgiske tilbudet i områder som har lav tilgang til kirurgi, og pasienter kan rekrutteres raskere til større og mer valide studier, sier Kjetil Søreide, som er overlege ved Gastrokirurgisk avdeling ved Stavanger universitetssjukehus og professor ved Klinisk institutt I, Universitetet i Bergen. - Studiers gyldighet vil øke om man rekrutterer pasienter fra flere land enn kun de vestlige. Randomiserte studier er ønskelig, men en rekke andre typer studier er også relevante for problemstillinger i kirurgiske fag, sier han.

- Forskningsnettverk og koordinatorsentre er allerede på vei i flere land, og støttefunk- sjoner trengs for å virkeliggjøre samarbeidsmulighetene mellom regioner. Vi trenger et universelt system som kan ivareta juridiske og etiske regler på tvers av nasjonale regulativer og lovhjemler, slik at internasjonale studier ikke hindres. Samarbeid om ny teknologi kan påskynde evaluering og implementering av nytt utstyr og nye teknikker. Bruk av elektroniske tjenester og internett kan lette arbeidet med slikt samarbeid og bør utnyttes der det er mulig, sier Søreide.

- Det er første gang strategier for kirurgiske fag er samlet på denne måten. Arbeidsgruppen håper rapporten vil inspirere flere kirurger til økt internasjonalt forskningssamarbeid, sier Søreide.

\section{International Research \\ Collaboration In Surgery (IRIS)}

Gruppen som har ledet arbeidet består av redaktørene i British Journal of Surgery og en forfattergruppe med representanter fra samtlige kontinenter. I tillegg har en større internasjonal gruppe (IRIS ad hoc working group), som består av kirurger fra flere fagretninger og land, blitt konsultert $i$ arbeidet med å finne nåværende barrierer og muligheter for økt samarbeid på tvers av kulturer, språk og fag. Litteratursøk ble benyttet for å identifisere aktuelle studier og eksempler.

\section{Matilde Risopatron Berg}

matilde.risopatron.berg@legeforeningen.no Tidsskriftet

\section{Litteratur}

1. Søreide K, Alderson D, Bergenfelz A et al. Strategies to improve clinical research in surgery through international collaboration. Lancet 2013 ; 382: $1140-51$

\section{THE LANCET}

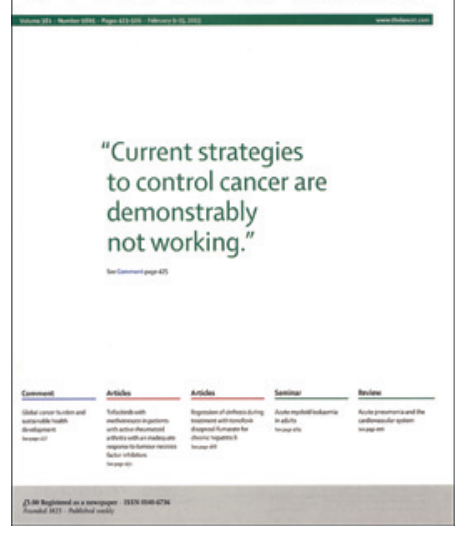

Artikkelen ble publisert i september 2013 i The Lancet, som regnes som en av de «fem store» innen medisinsk publisering ved siden av New England Journal of Medicine, JAMA, BMJ og Annals of Internal Medicine. 